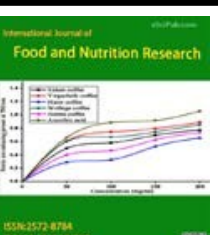

International Journal of Food and Nutrition Research (ISSN:2572-8784)

\title{
Chemical and microbiological properties of kavut flour produced in some regions of Turkey
}

\section{Asya ÇETINKAYA}

Kafkas University, Faculty of Engineering and Architecture,Department of Food Engineering, KarsTurkey

\section{ABSTRACT}

Kavut is a traditional cereal product prepared with kavut flour, *Correspondence to Author: which is obtained from grinding wheat or barley, and sugar, milk Asya ÇETINKAYA and butter. In this study, 35 unpacked kavut flour samples that Kafkas University, Faculty of Enwere produced in house conditions and family businesses in gineering and Architecture,DeKars province and sold in delicatessen and shopping arcades partment of Food Engineering, were analyzed chemically to determine their ash, moisture, Kars-Turkey acidity (\%), protein ratio and microbiologically to determine their Total Aerobic Mesophilic Bacteria (TAMB), coliform, mould and rope spores counts. Ash, moisture, protein and acidity ratios (\%) How to cite this article:

of flour samples were found to be within the limits specified in Asya ÇETINKAYA. Chemical and the Turkish Food Codex Communiqué on wheat flour. According microbiological properties of kavut to the results of the microbiological analysis, the count of TAMB, flour produced in some regions of mould and coliform bacteria were determined to be below the Turkey. International Journal of maximum acceptable limit defined in the Turkish Food Codex Food and Nutrition Research, 2019; Communiqué on Microbiological Criteria. In general, it was 2:17. observed that kavut flour is eligible for kavut production given its microbiological and chemical properties.

Keywords: Kavut, cereal-based product, wheat flour, chemical and microbiological properties

\section{eScîPub}

eSciPub LLC, Houston, TX USA. Website: http://escipub.com/ 


\section{Introduction}

In line with the increasing demand for traditional food items, an industry that is based on the production and marketing of such types of food items has nowadays been created in several countries. There are a great many of products called "traditional food" in our country and some of these products are almost forgotten. Kavut has a special place among these products due to reasons such as easy production, consumption and low cost.

Kavut is a traditional cereal product. It is widely consumed in the Eastern Anatolia Region, especially in Van and Iğdır. Consumption of kavut, which can be prepared in various ways, varies in Kars. It may be consumed in the form of soup with the addition of milk, sugar and/or fat as well as in squeezed form (1).

Kavut is a nutritious cereal product as it contains whole grain flour and/or seed and whole wheat barley flour and is prepared by mixing with other ingredients such as milk, fat and sugar. In addition, kavut is highly aromatic due to the roasting of the grains before the milling process (2). First of all, wheat and barley grains are roasted at a specific temperature and ground as a whole in the stone milling process. Kavut is prepared by roasting the cleaned, sorted out and washed wheat, which is milled through a hand mill, on iron plate and by adding milk, oil (butter or margarine) and sugar to the ground flour (3). Wheat grains are generally used for kavut production in and around Kars province (1).

Wheat, which is a staple food for approx. 35\% of the global population and accounts for approx. $20 \%$ of calories obtained from all food items across the world (4), is an indispensable element of human diet (5). Wheat, which has an important place among grains with the nutritional habits of the communities and versatile usage possibilities, is often consumed by processing into flour and especially as many semi-finished and/or finished products such as semolina, starch, bulgur, bread, pasta, cakes, biscuits and cookies. Wheat grain comprises chemically of carbohydrates $(65-75 \%)$, proteins $(7-18 \%)$, water $(8-14 \%)$, lipids $(1-3 \%)$, mineral substances (1-2\%) and trace amounts of vitamins and enzymes (6). Wheat seed is one of the most important sources of Vitamin $E$. It is also rich in Vitamins $B_{1}$ and $B_{6}(7)$. Most of the minerals in wheat such as $\mathrm{K}, \mathrm{P}, \mathrm{Mg}$, Ca ve $\mathrm{Na}$ is abundant in aleurone layer.

The main distinctions that separate wheat that contains a number of nutrients at various levels from other cereals are (8).

- The heavy trade and its great contribution to the economy as it is the raw material of bread, which is our staple food,

-It contains gluten proteins in its composition and thus, is suitable for bread making,

- It contains a significant portion of the nutrients within its body and can be easily enriched and supplemented in terms of insufficient nutrients,

- A considerable part of the composition (85$90 \%$ ) consists of dry matter; it has a low lipid content so that few problems arise during storage and transportation.

- It is in compliance with various soil and climate conditions, it can be easily produced and has a high yield, all of which are other important advantages of wheat (6).

Cereals are a low-cost, easy-to-provide, concentrated energy source and are commonly used for nutrition of people located in the underdeveloped regions, especially where imbalanced diet is wide, partly due to their protein content of whole biological value, neutral taste and aroma (9).

Whole wheat flour obtained by grinding the whole grains of wheat together with bran and germ parts is a source that is rich in dietary fiber, mineral substances, Vitamin B complex, antioxidants (phytic acid, glutathione and tocopherol etc.) and essential amino acids. It is also a suitable and low-cost energy source with its protein that has a good nitrogen balance and high starch content. The yearly increasing 
demand for whole wheat flour stems from its effects to reduce the risk of heart diseases, high blood pressure, colon cancer, diabetes and obesity $(10,11)$.

The maximum allowable values that can be found in cereal flours and cereal-based products in accordance with Turkish Food Codex Communiqué on Microbiological Criteria are defined as: TAMB bacteria count $10^{4}-10^{5}$ $\mathrm{cfu} / \mathrm{g}$ and $10^{3}-10^{5} \mathrm{cob} / \mathrm{g}$ for coliform bacteria and $10^{4}-10^{5} \mathrm{cob} / \mathrm{g}$ for mould count for cereal flakes and cereal-based products $(12,13)$.

A limited number of studies conducted in Turkey are available in connection with the microbiological quality of flour production. In one of these studies, when the results of microbiological analysis of flour samples obtained from 7 different points of Thrace region are evaluated, it is expressed that TAMB count in some points were above the acceptable limits stipulated in Turkish Food Codex (14).

In a study conducted to examine some microbiological properties of flours produced in a flour factory located in Bishkek city of Kyrgyzstan and compare them with Kyrgyz Standards and to establish a HACCP Plan for the flour production line, mould count was determined to be 1.68-2.38 $\log _{10} \mathrm{cob} / \mathrm{g}$ and $2.07 \log _{10} \mathrm{cob} / \mathrm{g}$ in average and 2.07-3.27 $\log _{10}$ $\mathrm{cob} / \mathrm{g}, 2.63 \log _{10} \mathrm{cob} / \mathrm{g}$ in average and 2.43$2.95 \log _{10} \mathrm{cob} / \mathrm{g}$ and $2.75 \log _{10} \mathrm{cob} / \mathrm{g}$ in average and 2.273 EMS/gr for rope (15).

Victor et al. (16) report that the most consumed cereals in Lesotho is corn flour and wheat flour. To this end, in their study conducted to determine the microbial and physicochemical properties of Corn and wheat flours in a milling company located in Lesotho, they report that whole wheat flour contains $13.31 \%$ moisture, $0.71 \%$ ash and $13.76 \%$ protein. Total bacteria count was found to be $4.78 \log _{10} \mathrm{cfu} / \mathrm{g}$ coliform bacteria were found to be $3.73 \log _{10} \mathrm{cfu} / \mathrm{g}$ and yeast-mould count was found to be $2.78 \log _{10}$ cfu/g.
Moisture content, ash and protein of flour samples obtained from 30 factories producing flour in 19 cities in seven regions of Turkey were found to be $9.59-14.17 \%, 0.52-0.82 \%$ and 9.36-10.49\%, respectively (17).

The relationship between the microbiological properties of raw material (flour and water) and hygiene parameters (surface, equipment, personnel and air) and microbiological properties of phyllo (finished product) has been studied for the first time in Turkey in phyllo production facilities. In flour samples, the mean TMAB count was found to be $1.5 \times 10^{4} \mathrm{cob} / \mathrm{g}$, the mean coliform bacteria count was found to be $4,4 \times 10^{1} \mathrm{cob} / \mathrm{g}$, the mean Staphylococcus count was found to be $9.3 \times 10^{2} \mathrm{cob} / \mathrm{g}$, the mean $\mathrm{S}$. aureus count was found to be $1.0 \times 10^{2} \mathrm{cob} / \mathrm{g}$ and the mean mould count was found to be $6.8 \times 10^{3} \mathrm{cob} / \mathrm{g}(18)$.

Demir (19) Moisture content and raw ash of wheat flours that is used for determining the effect of the use whole wheat grain on biscuit production on biscuit properties were found to be $10.30 \%$ and $1.42 \%$, respectively.

The mean protein ratios and ashes of 22 samples of baklava flour obtained from highcapacity flour factories and baklava producers in Konya, Gaziantep, Ankara, Izmir, Balikesir and Isparta are high-capacity flour factory and baklava producers were found to be $12.47 \%$ and $0.58 \%$, respectively (20).

This study aims to determine certain chemical and microbiological properties of the kavut flour used for kavut production, to improve the kavut production which has a different aroma and nutritive value, to increase the consumption and to offer it to consumers as a new cereal product.

\section{Materials and Methods}

Thirtyfive unpacked kavut flour samples that were produced in house conditions and family businesses in Kars province and sold in delicatessen and shopping arcades were used as a material. The samples were taken exactly 
as the sellers presented them to consumers

and brought to the laboratory and microbiological cultivation and some chemical analyzes were immediately performed.

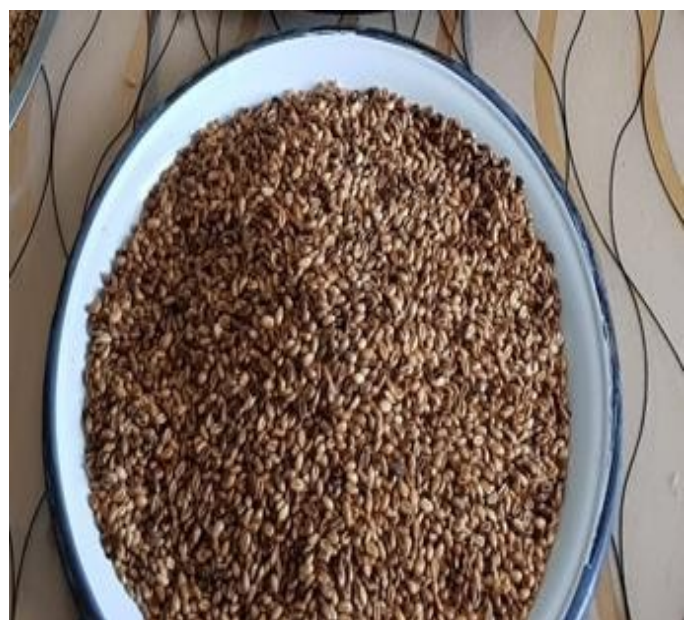

Figure 1. Roasted wheat grain

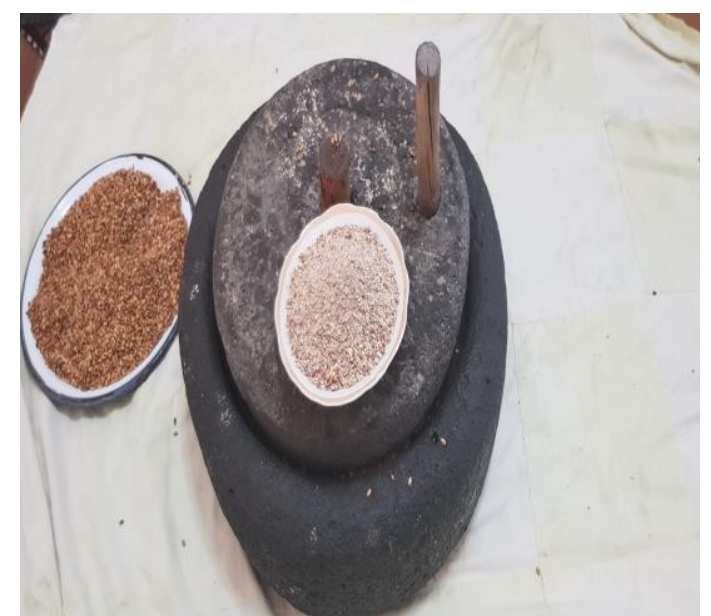

Figure 2. Kavut flour grinding mill (stone)

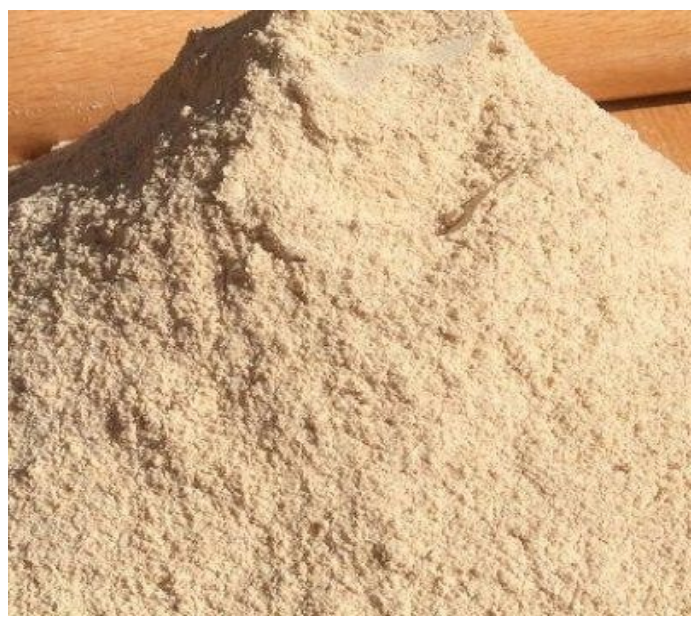

Figure 3. Kavut flour

\subsection{Chemical Analyses}

Ash content of the kavut flour samples ICC Standart Metod No: 104, raw protein amount AACC (American Assocation of Cereal Chemistry) Approved Metod No: 46-12 (21), moisture (22) and \% acidity (in sulphuric acid) were analyzed according to (IS 12711) (23).

\subsection{Microbiological Analyses}

$10 \mathrm{~g}$ of homogenized kavut flour samples were taken and homogenized with $90 \mathrm{ml}$ (1:10 dilution) sterile saline peptone water for $2 \mathrm{~min}$ and serial dilutions were prepared with sterilized $0.1 \%$ saline peptone water up to the level of $10^{7}$ and were cultivated from the respective dilutions to their medium. Plate Count Agar (Merck-M105463.0500) was used for Total Aerobic Mesophilic Bacteria count and spread plate technique was used for cultivation and they were incubated at $30{ }^{\circ} \mathrm{C}$ for $24-48$ hours. Pour plate method was used for coliform bacteria count and to this end, Violet Red Bile Agar (MerckM 101406.0500) used and count was performed following incubation at $37^{\circ} \mathrm{C}$ for 18-24 hours. Spread plate technique was applied for determining the mould count and Potato Dextrose Agar (Merck-M 110130.0500) was employed. Petri dishes were incubated at $25{ }^{\circ} \mathrm{C}$ for 5-7 days (24). Dextrose Tryptone Broth (Oxoid-CM0073B) was used for 
determining rope spores and triple tube EMS method was employed.

\subsection{Statistical Analysis}

In the evaluation of the obtained results, mean values and standard errors of the samples were determined using SPSS package program (Version 18) .

\section{Results and Discussion}

The analysis results of kavut flour samples are shown in Table 1 and Table 2.

Table 1. Chemical analysis results of kavut flour samples $(n=35)$ obtained from location in Kars, Turkey

\begin{tabular}{|c|c|c|c|c|}
\hline \multicolumn{5}{|c|}{ Parameters } \\
\hline \multicolumn{2}{|c|}{$\%$ Acidity ( in $\mathrm{H}_{2} \mathrm{SO}_{4}$ ) } & Moisture (\%) & Ash (\%) & Protein (\%) \\
\hline Minimum & 0.06 & 8.44 & 0.74 & 11.03 \\
\hline Maximum & 0.09 & 10.15 & 1.68 & 13.40 \\
\hline Mean $(x \pm S x)$ & $0.07 \pm 0.05$ & $9.05 \pm 0.11$ & $1.61 \pm 0.03$ & $13.05 \pm 0.14$ \\
\hline
\end{tabular}

Table 2. Microbial analysis results of kavut flour samples $(n=35)$ obtained from location in Kars, Turkey (Log cfu/g)

\begin{tabular}{lcccc}
\hline \multicolumn{5}{c}{ Microorganism } \\
\hline Minimum & TAMB & Coliform & Moulds & $\begin{array}{c}\text { Rope-spore counts } \\
<30\end{array}$ \\
\hline Maximum & 0 & 3.00 & 0 & $<30$ \\
Mean $(x \pm$ Sx $)$ & 5.54 & 5.00 & 3.43 & $<30$ \\
\hline
\end{tabular}

TAMB: Total aerobic mesophilic bacteria

oisture content and physico-chemical properties of flour are the main determinants of consumer acceptability and safety. Given the quality of flour and acceptability of flour products, moisture is a key parameter. It affects the shelflife and microbial growth during storage $(14,25$, 26).

The moisture content of kavut flour samples was determined to be $9.05 \%$. The value obtained is lower than the value determined by Aydin et al. (14) and Victor et al. (16) in flour samples; close to the lower limit of moisture content determined by Ercan and Seçkin (27) in foreign varieties of wheat grown in our country used for bread-making (9.41-10.72\%); within the limits $(7.9-10.70 \%)$ determined by Karaoğlu and Kotancilar (2) and higher than the value determined by Akhtar et al (28) in whole wheat flour $(8.83 \%)$.
The protein ratio plays a key role especially in the texture and flavour of the final product of wheat flour (29). The protein ratio is largely affected by environmental factors (21). However, it was reported that the protein ratio of grain could be increased through improvement without any decrease in yield (30). The growing techniques also affect the protein ratio (31). It was reported that the protein ratio was affected by soil, climate and fertilizer applications rather than variety and it varied by $6 \%-25 \%(21)$.

Protein ratios of kavut flour samples were found to be higher than the values determined by Ekinci and Unal (17) in flour samples taken from 19 cities in 7 regions in Turkey (9.36$10.49 \%)$; higher than the values determined by Aydın et al. (32) in wheat samples taken from the Central Black Sea Region (11.30-12.76\%), by Taşdemir (33) in flour samples taken from 
shopping arcades $(11.70 \%)$ and by YeyinliSavlak and Kose (20) in baklava flour (12.47\%); close to the values determined by Karaoğlu and Kotancilar (2) in kavut flour $(13.10-13.20 \%)$ and lower than the values found by Victor et al. (16) $(13.76 \%)$.

Ash ratios were found to be higher than the values determined by Yeyinli-Savlak and Kose (20) in baklava flour (0.58\%), by Aydın et al. (14) taken from 7 different points in Thrace Region $(0.54 \%)$ and by Victor et al (16) in the wheat flour consumed most in Lesotho $(0.71 \%)$ and by Demir (19) in wheat flour used in biscuit production $(1.42 \%)$ and close to the values determined by Karaoğlu and Kotancilar (2) in kavut flour (1.62-1.67\%).

Acidity ratio (\%) of kavut flour samples was determined to be $0.07 \%$ in average. Acidity (\%) (in $\mathrm{H}_{2} \mathrm{SO}_{4}$ ) was found to be within the limit specified in Turkish Food Codex Communiqué on wheat flour. The protein and ash contents of the kavut flour samples made from wheat that were examined were within the limits specified in the Communiqué (34) and their moisture content was found to be significantly lower than $14.5 \%$. Wheat grains used for kavut production are first roasted and then milled, which can be said to be a considerable factor in their low moisture content.

TAMB is widely used to get a general idea on the hygienic quality and microbiological load of foodstuffs (35).

TAMB count determined in kavut flour samples was higher than the value determined by Aydın et al. (14) in flour samples taken from 7 different points of Thrace Region (Turkey) (2.89-4.71 log cfu/g), by Semercioğlu (15) in samples from a flour factory located in Bishkek city of Kyrgyzstan (2.75 $\log _{10} \mathrm{cob} / \mathrm{g}$ in average) and by Arda and Aydın (18) in flour samples in phyllo production facilities in Turkey $\left(1.5 \times 10^{4} \mathrm{cob} / \mathrm{g}\right)$. It was found to be lower than the TAMB count specified in Turkish Food Codex Communiqué on Microbiological Criteria for all cereal-based products $\left(1.10^{5} \mathrm{cob} / \mathrm{g}\right)(12)$.
Coliform bacteria and Escherichia coli counts are important as they are indicators of general hygiene properties of foodstuffs. Coliform bacteria count in kavut samples was determined to be $2.10 \mathrm{log} \mathrm{cob} / \mathrm{g}$. The value is lower than the value determined by Arda and

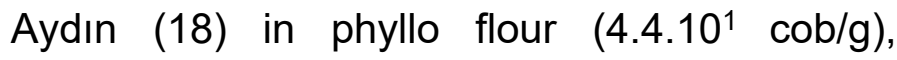
Semercioğlu (15) in flours in Bishkek city of Kyrgyzstan (2.60 log cob/g) and Victor et al (16) in wheat flours (3.73 log cfu/g). The mean coliform bacteria count in kavut flour samples was found to be below the maximum acceptable limit $\left(1 \times 10^{4} \mathrm{cob} / \mathrm{g}\right)(13)$.

There are many different factors for mould contamination in flour and some of these factors are cereal grains, contamination of cereal grains during flour making and low sanitation controls (18).

Mould count in all analyzed kavut flour samples was determined to be below the maximum acceptable limit $\left(1 \times 10^{5} \mathrm{cob} / \mathrm{g}\right)(13)$. Mould count determined by different researchers $(15,16,18)$ is higher than the values determined in the study.

Rope spores are Bacillus subtilis spores in food that are usually heat resistant (36). Bacillus subtilis is a soil-bacterium and its spores are often isolated from flour and may cause serious problems for bakery industry, especially bread. It was determined that none of the kavut flour samples, examined in our study, contained rope spores (<30 EMS/g).

Many factors such as type of wheat, climate conditions where it is grown, soil structure, harvest conditions and whether thermal treatment is applied or not are effective in the difference between the results of the chemical analysis of kavut flour samples examined and the study results of other researchers. The results obtained from the analyses were found to be within the limits stipulated in Turkish Food Codex Communiqué on wheat flour. The bacteria counts of TAMB, mould and coliform were found to be below the maximum acceptable limit. Kavut is a traditionally produced cereal product with a high nutritious 
value that can be prepared in different ways, is highly liked and consumed.

It can be said that further studies are required to determine the properties of kavut flour used in the production of kavut that is easy-toproduce and has a rich content and to spread its consumption.

\section{References}

1. Güngören, S. Personal communication. Kavut flour producer, Dikme Köyü, Kars/Turkey. 2018

2. Karaoğlu MM, Kotancılar HG. Kavut, a traditional Turkish cereal product: production method and some chemical and sensorial properties. International Journal of Food Science and Technology. 2006; 41:233-241.

https://doi.org/10.1111/j.1365-2621.2005.01053.x

3. Kulturportalı Customs-Traditions. [Internet]. [cited 2018 Agust 20].

https://www.kulturportali.gov.tr/turkiye/kars/kulturatlas i/kavut897536.

4. Balkan A, Gençtan T. Effects of different row spacing and seeding rate on grain yield and yield components in some bread wheat cultivars (Triticum aestivum L.). Journal of Agricultural Sciences. 2008; 14: 29-37. www.agri.ankara.edu.tr/journal

5. Akgün I, Altındal D, Kara B. 2011. Determination of suitable sowing dates for some bread and durum wheat cultivars under Isparta ecological conditions. Journal of Agricultural Sciences. 2011; 17(4): 300309. www.agri.ankara.edu.tr/journal

6. Kurtcebe A, Ercan R. Buğday unu komponentlerinin kompozisyonu ve fonksiyonları, Bitirme Ödevi, Süleyman Demirel Üniversitesi, Ziraat Fakültesi, Gıda Mühendisliği Bölümü, Isparta, 2001.

7. Köksel H, Aktan B, Sivri D. Studies on the effects of various heat treatment methods on the electrophoretic properties of wheat germ proteins. Turkish Journal of Agriculture and Forestry. 1993; 17: 139-148. http://journals.tubitak.gov.tr/agriculture/ T

8. Karatekin E. Süne zararına uğramış buğday ununun katkı maddeleri kullanılarak ekmeklik kalitesinin iyileştirilmesi, Yüksek Lisans Tezi, Çukurova Üniversitesi Fen Bilimleri Enstitüsü, Adana. 2008.

9. Elgün A, Ertugay Z. Tahıl İşleme Teknolojisi, Atatürk Üniv. Ziraat Fak. Yayanları (Ders Notları, 3, Baskı), Yayın No: 297, Erzurum, 1997.

10. Elgün A, Demir MK. 2008. Tam buğday unu ve fonksiyonel özellikleri. Türkiye 10. Gıda Kongresi: 2123 Mayıs, Erzurum, 2008; 49-52.
11. Slavin JL. Mechanisms for the impact of whole grain foods on cancer risk. Journal of the American College of Nutrition. 2000; 19: 300-307.

https://doi.org/10.1080/07315724.2000.10718964

12. Turkish Food Codex. Mikrobiyolojik Kriterler Tebliği, Resmi gazete, (06.02.2009), Tebliğ No: 2009/6, Başbakanlık Yayınları, Ankara.2009.

13. Turkish Food Codex. Mikrobiyolojik Kriterler Tebliği, Resmi gazete, (29.12.2011) Başbakanlık Yayınları, Ankara. 2011.

14. Aydın A, Paulsen P, Smulders F. The physicochemical and microbiological properties of wheat flour in Thrace, Turkish Journal of Agriculture and Forestry. $\quad 2009$; 33: 445-454.

http://dergipark.gov.tr/download/article-file/119691

15. Semercioğlu E. Un üretim hattının bazı mikrobiyolojik tehlikeler yönünden incelenmesi. Kırgızistan Türkiye Manas Üniversitesi, Fen Bilimleri Enstitüsü, Gıda Mühendisliği Anabilim Dalı. Aralık 2016, Kırgızistan/Bişkek. 2016.

16. Victor N, Bekele MS, Ntseliseng M, Makotoko M. Microbial and physicochemical characterization of maize and wheat flour from a milling Company Lesotho. International Journal Food Safety. 2013; 15:11-19.

https://www.researchgate.net/publication/277006463

17. Ekinci R, Unal $S$. Türkiye'nin farklı bölgelerinde üretilen değişik un tiplerinin özellikleri I. Bazı kimyasal ve teknolojik özellikleri. Gıda. 2002; 27(3) 3: 201-207.

18. Arda Ş, Aydın A. A study on the relationship of thin sheet of dough microbiological quality between quality of raw material and some hygiene parameters. İstanbul Üniversitesi Veteriner Fakültesi Dergisi. 2011; 37 (2): 135-147.

http://vetjournal.istanbul.edu.tr/archive/2011_2/135_1 47.pdf

19. Demir MK. 2015. Utilization of whole wheat flour and its blends in cookies production. Journal of Agricultural Sciences. 2015; 21: 100-107.

www.agri.ankara.edu.tr/journal

20. Yeyinli-Savlak N, Köse E. Physical, Physicochemical and Rheological Properties of Baklava Flours Produced in Turkey. Turkish Journal of Agricultural and Natural Sciences. 2014; 1(2): 219-226. www. turkjans.com

21. Anonymous International Assocation for Cereal Chemistry. 1990

22. Anonymous 1976. International Assocation for Cereal Chemistry. (ICC) Standard Methods No: 110.

23. Bakery products - Methods of analysis. 1989. Author: Bureau of Indian Standards (BIS), Govt. of 
India. Edition : 1989. Media : Paper Back. (IS12711). . 1989.

24. Anonymous. Merck Practise of Food Microbiology. Basak Matbaacılık Ltd Sti. Ankara. Turkey. pp: 1-358. 2005.

25. Batool SA, Rauf N, Tahir SS, Kalsoom R. Microbial and physico-chemical contamination in the wheat flour of the twin cities of Pakistan. International Journal Food Safety. 2012; 14: 75-82.

https://pdfs.semanticscholar.org/de0f/0a83450ed5bef e34a0cd786ccfdc081ec0a1.pdf

26. ICMSF. Microorganisms in Foods: 6 Microbial ecology of food commodities. Blackie Academic and Professional, London, 1998; 313-346.

27. Ercan R, Seçkin R.. Ülkemizde yetiştirilen yabancı ekmeklik buğday çeşitlerinin kalitesi. Gıda. 1989; 14(6): 353-361.

28. Akhtar S, Anjum FM, Ur Rehman S, Sheikh MA, Farzana K. 2008. Effect of fortification on physicochemical and microbiological stability of whole wheat flour. Food Chemistry 2008; 110: 113-119. https://www.ncbi.nlm.nih.gov/pubmed/26050173

29. DeMan JM. Principles of food chemistry, 2nd ed. Van Nostrand Reinhold, New York. 1990

30. Miezan K, Heyne EG, Finney KF. Genetic and environmental effects on the grain protein content in wheat. Crop Science.1977; 17: 591-593.

31. Cook, R.J. \& Veseth, R.J. 1991. Wheat Health Management. The American phytopathological society, St. Paul, Minnesota 55121, USA.

32. Aydın, N., Bayramoğlu HO, Mut Z, Özcan H. Determination of yield and quality characters of bread wheat (Triticum aestivum L.) cultivars and lines under Black Sea Region conditions of Turkey. Journal of Agricultural Sciences. 2005; 11(3): 257-

262. www.agri.ankara.edu.tr/journal

33. Taşdemir B. Değişik Un pasajlarının bazı geleneksel ekmek çeşitlerine uygunluğunun belirlenmesi Ankara Üniversitesi, Fen Bilimleri Enstitüsü, Gıda Mühendisliği Anabilim Dalı. 2005.

34. Turkish Food Codex. Türk Gıda Kodeksi Buğday Unu Tebliği, Resmi Gazete, (09.10.2018), Tebliğ No : 2018/39, sayı: 30560. 2018.

35. Morton RD. Aerobic plate count, In: Microbiological Examination of Foods, (Eds. PF Downes, $\mathrm{K}$ Ito), American Public Health Association, Washington DC, 2001; 63-67.

36. Adams MR, Moss MO. Food Microbiology, Royal Society of Chemistry, Cambridge.1995. 